\title{
Influence of temperature on surface sediment disturbance by freshwater fish: a microcosm experiment
}

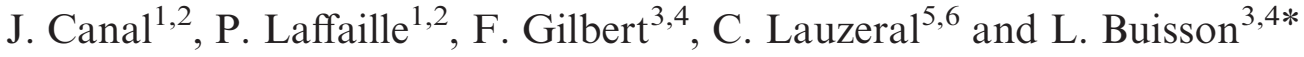 \\ ${ }^{1}$ Université de Toulouse, INP, UPS, EcoLab (Laboratoire Ecologie Fonctionnelle et Environnement), ENSAT, Avenue de \\ l'Agrobiopole, 31326 Castanet Tolosan, France \\ 2 CNRS, EcoLab, 31326 Castanet Tolosan, France \\ 3 Université de Toulouse, UPS, INP, EcoLab (Laboratoire Ecologie Fonctionnelle et Environnement), 118 route de Narbonne, \\ 31062 Toulouse Cedex 9, France \\ ${ }^{4}$ CNRS, EcoLab, 31055 Toulouse, France \\ ${ }^{5}$ UMR 5174 EDB (Laboratoire Evolution et Diversité Biologique), CNRS, 31062 Toulouse, France \\ ${ }^{6}$ Université de Toulouse, UPS, EDB, 118 route de Narbonne, 31062 Toulouse, France
}

Received 11 July 2014; Accepted 27 March 2015

\begin{abstract}
Water temperature is a key parameter that regulates activities of ectotherms (e.g., fish) and has been projected to rise in the future in the context of climate change. Surface sediment disturbance (SSD) is an important function performed by fish that modifies benthic habitat properties and may thus influence ecosystem functioning. However, the link between SSD by fish and temperature remains unexplored. In this study, we experimentally assessed the influence of two contrasted temperatures (10 versus $20^{\circ} \mathrm{C}$ ) on $\mathrm{SSD}$ by three freshwater fish species in aquaria. After 10 days, the total surface disturbed by the species was approximately 2-3 times higher at warm than at cold temperature but the number and area of patches disturbed by the species were not significantly different. The stone loach Barbatula barbatula, a benthic fish species, had a higher SSD activity (i.e., total surface disturbed, number and size of patches disturbed) both at cold and warm temperatures than two cyprinid species, chub Squalius cephalus and sofie Parachondrostoma toxostoma. On average, SSD by B. barbatula resulted in approximately two and three more patches than the cyprinid species at 10 and $20^{\circ} \mathrm{C}$, respectively, and the mean patch area disturbed by B. barbatula was about two times larger than the ones disturbed by the cyprinid species. The total surface disturbed by the cyprinids at warm temperature was roughly equivalent to the surface disturbed by B. barbatula at cold temperature. Our results thus suggest that SSD by fish could increase in future warmed conditions.
\end{abstract}

Key words: bioturbation / Barbatula barbatula / Parachondrostoma toxostoma / Squalius cephalus / zoogeomorphology

\section{Introduction}

Given the growing interest in understanding the changes of physical environment induced by organisms (Statzner, 2012), bed sediment reworking by a variety of animal species acting as zoogeomorphic agents has been extensively studied in the bioturbation research field both for marine and freshwater environments (e.g., macroinvertebrates: Cadée, 1979; Caradec et al., 2004; Heldman et al., 2011; Marmonier et al., 2012; Zhang et al., 2014; molluscs: Orvain and Sauriau, 2002; Gilbert et al., 2007; crayfish: Statzner et al., 2003a; Statzner and Peltret, 2006; Johnson et al., 2010; mammals: Jones et al., 1994).

\footnotetext{
*Corresponding author: laetitia.buisson@univ-tlse3.fr
}

Among this fauna, many studies have focused on fish as actors of bed surface disturbance in streams (e.g., Flecker, 1996; Flecker and Taylor, 2004; Holtgrieve and Schindler, 2010), given their key role in the flux and transfer of particles and solutes in aquatic ecosystems. The influence of spawning behaviour of salmonid species on streambed has been extensively documented (e.g., Montgomery et al., 1996; Peterson and Foote, 2000; Gottesfeld et al., 2004; Moore et al., 2007; De Vries, 2012) but knowledge of other behaviours as zoogeomorphic activity (e.g., foraging, swimming and burrowing) remains scarce, especially for non-salmonid species (but see Statzner and Sagnes, 2008; Shirakawa et al., 2013; Pledger et al., 2014).

Bed sediment reworking by fish can result from a wide range of activities and be a substantial source of 
disturbance to benthic habitat (Moore, 2006) and ecosystem functioning. For example, De Vries (2012) showed that salmonids, by digging nests during the reproduction season, cause a strong local reworking of the streambed sediment. Spawning runs of sockeye salmon have also been reported to increase temporarily surface gravel size and invertebrate drift while decreasing periphyton biomass (Peterson and Foote, 2000). Shirakawa et al. (2013) also recently highlighted that the burrowing and feeding behaviour of larval lampreys caused increased oxygen levels and bioturbation in the streambed. Fish swimming movement close to, or directed at the streambed can also cause significant modifications of bed sediment structure (Statzner and Sagnes, 2008), as can the excavation of shelters (Reise, 2002).

Temperature plays a fundamental role in regulating the physiological and biochemical processes of fishes (Fry, 1947; Brett, 1971), acting on physiology as a lethal factor (below or beyond the thermal tolerances of species) or as a stress factor (Elliott, 1981). Consequently, temperature controls the fish activities (e.g., reproduction, migration and feeding).

The assessment of the effects of temperature on fish activity is a significant challenge in the context of climate warming (Harborne, 2013), given that fish may influence habitat features and ecosystem functioning through both trophic and non-trophic activities (Shirakawa et al., 2013). Although some studies have assessed the role of temperature in regulating the activity of sediment reworking (e.g., White et al., 1987; Ouellette et al., 2004), these have not yet assessed this for freshwater fish. The studies completed on other biota suggested a strong relationship between sediment reworking and water temperature, both in marine and freshwater systems. For instance, White et al. (1987) reported a 90\% decline in sediment reworking rate by oligochaetes from the Laurentian Great Lakes when temperature was experimentally lowered from 10 to $4{ }^{\circ} \mathrm{C}$. Ouellette et al. (2004) documented a higher sediment transport by a marine polychaete species at warm (13 and $\left.18{ }^{\circ} \mathrm{C}\right)$ than at cold $\left(1\right.$ and $\left.6^{\circ} \mathrm{C}\right)$ temperatures. Similar trends were found for the bioturbation activity by a heart urchin (Hollertz and Duchêne, 2001) or the reworking rate by a surface deposit-feeding bivalve (Maire et al., 2007). In another study, Berkenbusch and Rowden (1999) have followed the rate of sediment expulsion by the burrowing shrimp Callianassa filholi at an intertidal sandflat in New Zealand over a 12-month period. They found that sediment expulsion was significantly related to seawater temperature, being maximal in summer and dropping to a minimum at the end of winter.

In the context of climate change, all these findings thus suggest that surface sediment reworking by biological organisms could increase with the rapid on-going warming, as long as temperature does not exceed their upper thermal tolerance. Fish, especially warm-water species, are acknowledged to be more active at warm than at cold temperatures (López-Olmeda and Sánchez-Vázquez, 2011). Consequently, we assume that benthic foraging fishes preferring cool and warm waters could increase sediment displacement and transport due to their feeding and locomotor activity in response to water warming. Given that cool- and warm-water fish species are also expected to expand their spatial distribution (Buisson et al., 2008; Lyons et al., 2010), the increase in surface sediment disturbance (SSD) by benthic species might have important implications for bedload sediment flux at local and larger scales (Statzner and Sagnes, 2008), and subsequently on biogeochemical processes and ecosystem functioning (e.g., Persson and Svensson, 2006a). For instance, the micro-topography of the surface of sediment could change and its erodibility by water rise due to more intensive disturbance by fish (Pledger et al., 2014). Benthivorous fish species (e.g., Cyprinus carpio, Abramis brama) are also known to influence directly and indirectly water quality (i.e., nutrients, suspended solids and organic matter) and biological communities (e.g., macrophytes, phytoplankton, zooplankton and macro-invertebrates) through nutrients and organic matter release from the resuspension of sediments to the water column due to bioturbation (i.e., by feeding) but also excretion (Breukelaar et al., 1994; Persson and Svensson, 2006a; Roozen et al., 2007; Matsuzaki et al., 2009). Hence, changes in SSD by benthic fish in response to water warming could lead to a wide range of disturbances in ecosystem functioning, among which changes in primary productivity by a spatial redistribution of the micro-phytobenthos (Orvain et al., 2004), increases of the water turbidity (Breukelaar et al., 1994; Matsuzaki et al., 2009), changes in nutrient recycling (Biles et al., 2002; Ieno et al., 2006), modifications in the texture of the sediment (Montserrat et al., 2009) or redistribution of macro-invertebrates in the first centimetres of the substrate (Persson and Svensson, 2006b; Maire et al., 2010).

In that context, the aim of our study was to experimentally assess the influence of contrasted temperatures on SSD by three benthic freshwater fish species with different temperature tolerance limits. Following the results of earlier studies, we hypothesized that SSD by cool- and warm-water fishes could rise with temperature warming due to increased foraging and swimming activity. Coldwater benthic species may also become more active due to thermal stress but changes in SSD may also depend on the intensity of warming. These results may help to better understand how temperature warming may modify the role of fish in particles movement.

\section{Material and methods}

\section{Fish species}

Three species of freshwater fish were utilized during the experiment: the chub Squalius cephalus L. 1758, the sofie Parachondrostoma toxostoma (Vallot 1837), and the stone loach Barbatula barbatula L. 1758. Due to various activities, they are assumed to disturb surface sediment (e.g.,De Nadaï-Monoury et al., 2013). B. barbatula buries in sediment for refuge and forages by sucking in large 
amounts of sediment, extracting a wide variety of small benthic invertebrates and plants, and releasing the sediment (Keith et al., 2011). P. toxostoma feeds mainly by grazing on benthic algae, diatoms and invertebrates (Chappaz et al., 1989; Keith et al., 2011), whereas $S$. cephalus is an opportunistic feeder eating both pelagic and benthic material (Hellawell, 1971; Keith et al., 2011). Both $P$. toxostoma and S. cephalus are also able to displace sediments when moving close to the streambed (see Statzner and Sagnes, 2008 for other cyprinid species; personal observation). In France, these three species are abundant in small rivers and large streams of trout and barbel zones (Huet, 1959) with riffles and pools and mainly covered by pebble-gravel and sandy substrates (Keith et al., 2011). These species were selected according to their contrasted thermal requirements. B. barbatula is indeed a cold- to cool-water species whose upper tolerance limit does not exceed $19^{\circ} \mathrm{C}$ (Elliott et al., 1996), while the two other cyprinid species prefer warmer waters with an optimum temperature ranging between 12 and $25^{\circ} \mathrm{C}$ depending on species and regions (Horoszewicz, 1973; Mann, 1976; Elliott, 1981; Bouchard et al., 1998; Gozlan, 1998; Souchon and Tissot, 2012). When modelling the distribution of stream fish species at the European scale, Logez et al. (2012) found a thermal range between 14.1 and $22.6^{\circ} \mathrm{C}$ for the stone loach and between 14.7 and $25.8^{\circ} \mathrm{C}$ for the chub. These three species were also shown to have contrasted response to future climate change in terms of spatial distribution (Buisson et al., 2008). Consequently, warmer temperature might have a different effect on SSD by these three fish species.

\section{Fish sampling and acclimatization}

Sixteen individuals of each three fish species were collected by electrofishing in spring 2011. S. cephalus and $P$. toxostoma were sampled in the Volp River, whereas B. barbatula was sampled in the Saudrune River. These two streams are located in the Garonne River catchment (Southwestern France). Water temperature in the two streams during the sampling was approximately $14{ }^{\circ} \mathrm{C}$. The mean total length and mass of the fish caught was $81.6 \pm 8.1 \mathrm{~mm}$ and $5.2 \pm 0.9 \mathrm{~g}, 108.7 \pm 18.6 \mathrm{~mm}$ and $12.7 \pm 2.6 \mathrm{~g}$ and $112.6 \pm 13.3 \mathrm{~mm}$ and $10.2 \pm 2.5 \mathrm{~g}$, for B. barbatula, S. cephalus and P. toxostoma, respectively.

At the laboratory, fish species were separated in three acclimatization opaque tanks $(500 \mathrm{~cm}$ long, $200 \mathrm{~cm}$ wide, $100 \mathrm{~cm}$ high) filled with water extracted from the river where fish were sampled and placed in a temperaturecontrolled room $\left(15^{\circ} \mathrm{C}\right.$ for the first 2 days of acclimatization) under a 12:12 $\mathrm{h}$ light regime. Two days after the introduction of fishes into the acclimatization tanks, temperature was increased or decreased by $0.5^{\circ} \mathrm{C}$ every $12 \mathrm{~h}$ until reaching the experimental temperature. The experiments were conducted at 10 and $20^{\circ} \mathrm{C}$ thus representing on average colder and warmer conditions than the temperature experienced by fish in the days before sampling, but going no further than the lethal temperatures of the three fish species (Keith et al., 2011; Souchon and Tissot, 2012). In addition, these two temperatures were quite realistic according to water temperature measured at present in the small rivers and large streams of trout and barbel zones in the Garonne catchment (ALADIN model: Bubnová et al., 1995; Sevault et al., 2014). They were also relevant in the context of climate change given the air temperature warming forecasted for the end of $21 \mathrm{st}$ century in an area of $1536 \mathrm{~km}^{2}$ including the two streams where fish were sampled (Sevault et al., 2014). Indeed, under the most severe climate change scenario (RCP 8.5), the mean monthly temperature is forecasted to become higher than $10^{\circ} \mathrm{C}$ from March to November (i.e., 9 months) and exceed $20^{\circ} \mathrm{C}$ from June to September in the future (mean over 2076-2100), whereas it only exceeds $20^{\circ} \mathrm{C}$ in August and is higher than $10^{\circ} \mathrm{C}$ from April to October (i.e., 7 months) at present (1981-2005). Hence, comparing these two contrasted and realistic temperatures enabled to test for the effect of future water warming on SSD by the three fish species and better understand potential implications for physical processes and ecosystem functioning.

During the acclimatization period, fishes were fed with dead chironomid larvae, and water in the tanks was gradually diluted with dechlorinated tap-water. Two days before the experiment, fishes were starved to optimize their foraging behaviour during the experimental period. No damage to individual fish was observed at the end of this starvation period.

\section{Experimental design}

The cost-effective method proposed by De NadaïMonoury et al. (2013) was used to experimentally quantify SSD by fish. For technical reasons, the experiments were conducted in aquaria without any flow, hence rather mimicking lentic than lotic environmental conditions. Opaque glass aquaria (40 cm long, $25 \mathrm{~cm}$ wide, $25 \mathrm{~cm}$ high) were placed in temperature-controlled rooms and filled with a $5-\mathrm{cm}$ layer of commercial white quartz sand (1-2.5 $\mathrm{mm}$ in diameter). A thin layer of dark blue sand (same diameter as the white sand) was used as tracers and then meticulously sprinkled on the white sand surface. Finally, tap water (about $18 \mathrm{~cm}$ high) was added in the aquaria, paying attention not to disturb the sediment layer, and then dechlorinated for 2 days. Aquaria were placed on polystyrene plates (20-mm thick) to isolate them from vibrations and lighted by an indirect light source (12:12 h light regime), to reduce fish stress.

Given the dimensions of the aquaria used, a single fish was placed in each aquarium resulting in a density of ten individuals per square meter. This density is higher than natural densities observed in streams but is consistent with patch-scale densities often observed during low-flow periods. It is worth noting that the behaviour of single fish placed in an aquarium is likely different from what is observed in the wild, especially for cyprinid species that naturally shoal. However, this experimental design 
enabled us to avoid potential interactions between fishes and additive surface disturbance due to multiple interacting fishes. For each temperature, experiments included eight replicates of each species, and three control microcosms to quantify sediment displacements due to handling or gravity in fish absence. At the end of the experiment, fishes were released back into the streams from where they had been collected.

\section{Assessment of the SSD}

Using a digital camera (Canon EOS 20D) mounted on a tripod, a picture of the initial sediment layer was taken directly above each aquarium before introducing the fish (Fig. 1(a)). Then, pictures of the sediment layer were taken daily to follow the changes in the sediment over the course of the experiment. The pictures were taken quietly with the fish within the aquarium to limit sudden and abrupt movements due to stress that could result in non-natural SSD. Appearance of white sand within the blue sand surface layer reflected the intensity of SSD by fish and spatial patterns of bed disturbed were also analysed. We stopped the experiment after 10 days (Fig. 1(b)) as most of the surface appeared to have been disturbed and the disturbed surface stopped increasing (see De NadaïMonoury et al., 2013 for more details).

SSD was quantified using several metrics. First, the proportion of surface disturbed was measured. Automatic pixel counts estimating the surface occupied by appearing white sand relative to the total surface of the aquarium were performed using image analysis software Image-Pro Plus (MediaCybernetics, Inc; see De Nadaï-Monoury et al., 2013 for a detailed description of pictures processing). Second, spatial patterns in the disturbed surface were analysed using the packages raster and SDMTools in the R environment software ( $\mathrm{R}$ Development Core Team, 2011). They enabled calculation of the number and size of patches of appearing white sand (Fig. 1(c)). A patch was defined as adjacent grains of white sand, i.e. white sand grains sharing a border or at least a corner (Queen's method; Hijmans and van Etten, 2013). To avoid overestimating the number of patches due to isolated sand grains, only patches made up of more than five grains of white sand were counted. The proportion of disturbed surface as well as both the number and mean size of the patches were divided by the mass of the fish to ensure robust comparisons between individuals and species. For all three metrics, the sediment surface under the fish was not accounted for in the computation of SSD.

\section{Statistical analyses}

Given small sample sizes, a non-parametric equivalent of a two-way analysis of variance with replication (Scheirer-Ray-Hare test; Scheirer et al., 1976) was performed to determine whether temperature (here, considered as a factor) and/or species significantly influenced

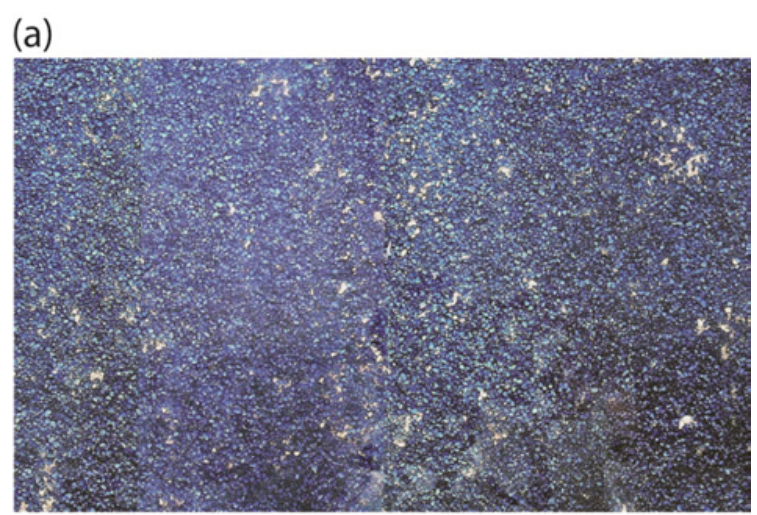

(b)

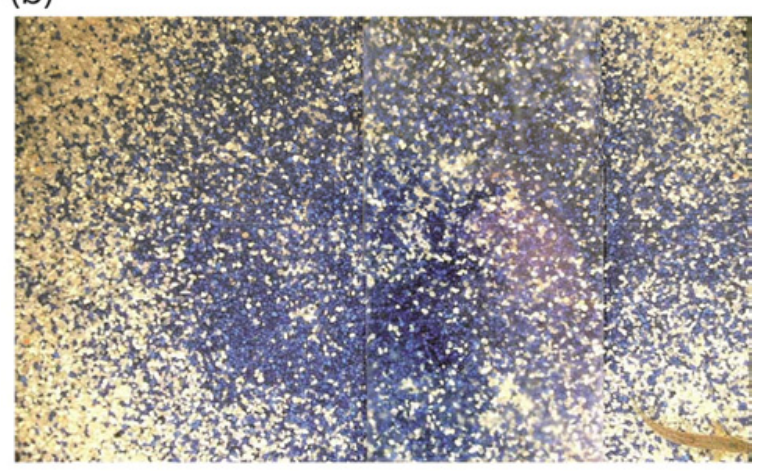

(c)

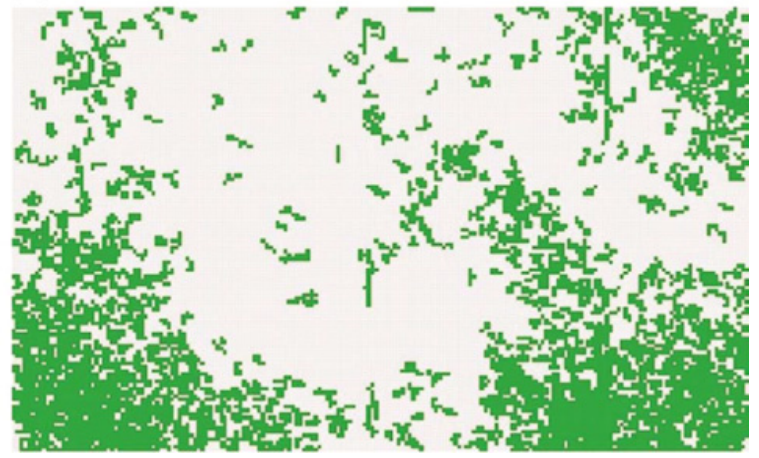

Fig. 1. Picture of the surface of an aquarium at (a) the beginning of the experiment, (b) after 10 days of sediment disturbance, and (c) after image treatment. An uniform blue sand layer had been sprinkled above a surface of white sand before one fish has been placed in the aquarium and sediment disturbance activity daily measured by picture analyses.

the proportion of disturbed surface at the end of the experiment, as well as the number and size of the patches disturbed. Then, comparisons between pairs of species and temperature were performed by Mann-Whitney tests and $P$-values were adjusted with the Bonferroni correction.

To determine whether SSD by fish was clustered or not, the spatial randomness of the point patterns derived from the sediment disturbance activity of fish was tested using the simple quadrat method (Greig-Smith, 1952; Cressie, 1993). Complete Spatial Randomness (CSR) assumes that points (here, white sand grains) follow a homogenous Poisson process over the study area and thus, that the 

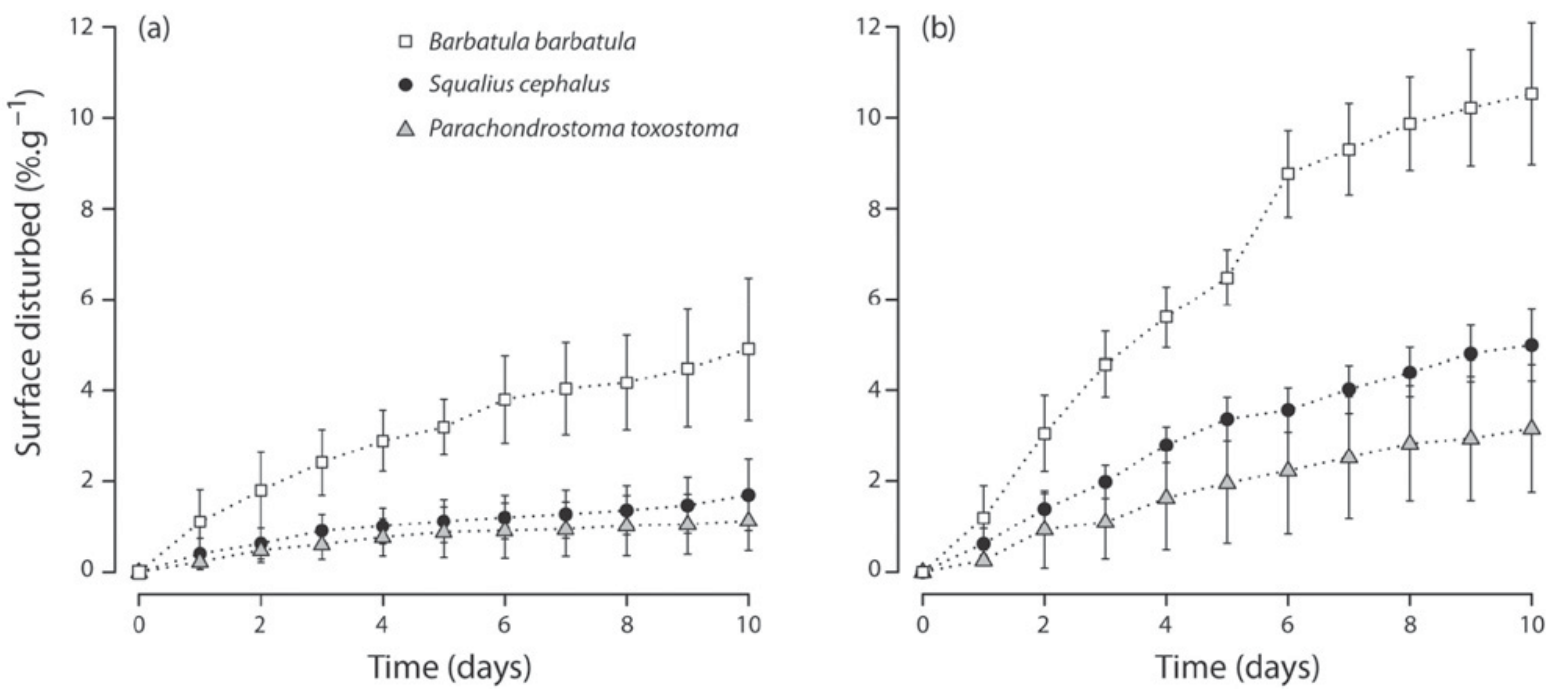

Fig. 2. Mean percentage of surface disturbed per gram of fish at (a) $10^{\circ} \mathrm{C}$ and (b) $20^{\circ} \mathrm{C}$ for the three fish species studied for the 10 -day experiment period. The bars shown are standard deviations calculated across eight individuals for each species and temperature.

density of white sand grains is constant over the whole aquarium surface. The quadrat method estimated how intensity of white sand grain patterns varied over the aquarium surface by counting points in delimited quadrats. Given that the result of the test depends on the size of the quadrats, the aquarium surface was partitioned in quadrats ranging from 1 to $250 \mathrm{~cm}^{2}$. Quadrat tests were performed using the package spatstat of the R environment software (R Development Core Team, 2011).

\section{Results}

In absence of fish (controls), no changes in the sediment surface were measured. In aquaria with fish, SSD was detected shortly after the fishes were introduced in aquaria (day 1) and the proportion of surface disturbed by the three fish species steadily increased for the 10 days of experiment, at both temperatures (Fig. 2). Both cyprinid species $P$. toxostoma and $S$. cephalus had comparable kinetics at $10{ }^{\circ} \mathrm{C}$ (Fig. 2(a)) but differed at $20^{\circ} \mathrm{C}$ with higher disturbance by $S$. cephalus over the experiment (Fig. 2(b)). Throughout the 10 days of experiment, $B$. barbatula had a higher sediment disturbance activity than both cyprinid species at both temperatures (surface disturbed approximately 3-4 and 2-4 times higher for B. barbatula at 10 and $20^{\circ} \mathrm{C}$, respectively; Fig. 2).

After 10 days of experiment, sediment surface disturbed appeared significantly clustered (i.e., patches of appearing white sand) for all three species and temperatures (CSR; $P<0.001)$ whatever the size of the quadrats chosen except for two individuals of $S$. cephalus at $20^{\circ} \mathrm{C}$ for the largest quadrat size.

When comparing the sediment surface after 10 days between species and temperatures, the proportion of white sand disturbed (Fig. 3(a)) varied depending on species (Scheirer-Ray-Hare; $H_{2,42}=23.4, P<0.001$ ) and temperature $\left(H_{1,42}=14.7, P<0.001\right)$, while the number
(Fig. 3(b)) and size (Fig. 3(c)) of white sand patches significantly differed between species (number of patches: $H_{2,42}=33.4, \quad P<0.001$; size of patches: $H_{2,42}=30.8$, $P<0.001$ ) but not between temperatures (all $P>0.05$ ). For the three species, the proportion of sediment surface disturbed was significantly higher (approximately 2-3 times higher depending on species; Table 1) at $20{ }^{\circ} \mathrm{C}$ than at $10{ }^{\circ} \mathrm{C}$ (Mann-Whitney; all $P<0.05$; Fig. 3(a)), with an average of $10.5,5.0$ and $3.2 \% . \mathrm{g}^{-1}$ of aquarium surface for $B$. barbatula, $S$. cephalus and $P$. toxostoma, respectively, at $20{ }^{\circ} \mathrm{C}$. At both temperatures, B. barbatula significantly disturbed a larger surface with more and larger patches than $S$. cephalus (Mann-Whitney; $P<0.05$ ) and $P$. toxostoma (Mann-Whitney; $P<0.05$ ) (Fig. 3). On average, SSD by $B$. barbatula after 10 days resulted in 2.6 and 1.9 more patches at $10{ }^{\circ} \mathrm{C}$ than $S$. cephalus and $P$. toxostoma, respectively, and 3.3 and 2.5 more patches at $20{ }^{\circ} \mathrm{C}$ (Table 1). The mean patch area disturbed by $B$. barbatula was about two times larger than the patches disturbed by the two cyprinid species at both temperatures (Table 1). There was no significant difference in the proportion of surface disturbed and patterns of SSD (i.e., number and size of patches) between $S$. cephalus and $P$. toxostoma at both 10 and $20^{\circ} \mathrm{C}$ (Mann-Whitney; all $P>0.05$; Fig. 3; Table 1).

\section{Discussion}

This study is one of the first to investigate the potential influence of temperature on the intensity of SSD by freshwater fishes. So far, the only studies dealing with the effect of temperature on sediment disturbance were conducted for marine invertebrates (e.g., Hollertz and Duchêne, 2001; Ouellette et al., 2004; Maire et al., 2007). They all reported an increase in sediment reworking with rising temperature. Our results highlighted that the three freshwater fish species considered were more active in SSD at 

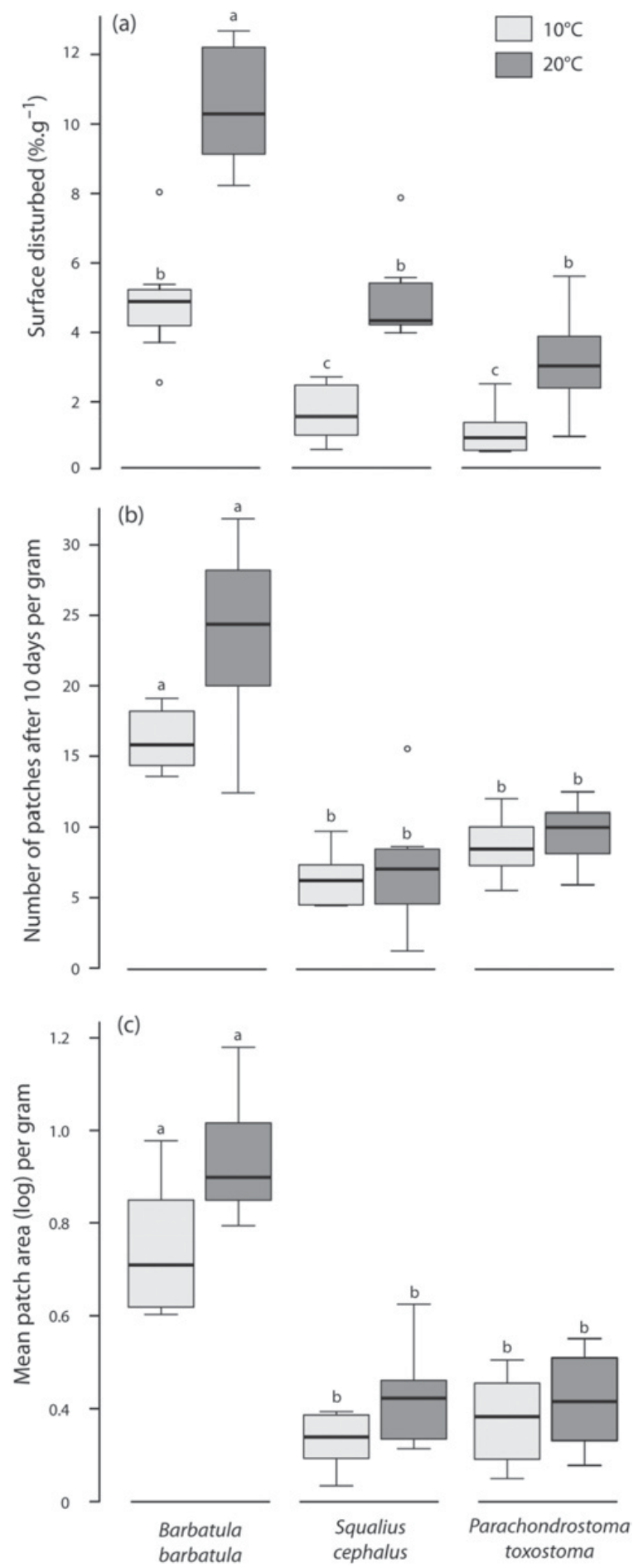

Fig. 3. SSD by fish after 10 days of experiment: (a) percentage of sediment surface disturbed per gram of fish; (b) number of white sand patches per gram of fish; (c) mean patch area (log transformed) per gram of fish. Different letters indicate significant differences $(P<0.05)$ between factors according to multiple pairwise Mann-Whitney tests and adjustments of $P$-values by a Bonferroni correction.

warm than at cold temperature confirming these previous findings. It is well known that temperature is one of the major drivers of the biology and activities of ectothermic animals. Several studies have demonstrated that temperature controls many biochemical processes of metabolic rate (Gillooly et al., 2001; Brown et al., 2004) and that a warmed temperature leads to an increase in basal and active metabolic rate as well as rates at which energy reserves are used by ectothermic organisms (Kassahn et al., 2009). Increases in the rate of physiological processes enable to raise fish activity among which locomotor (López-Olmeda and Sánchez-Vázquez, 2011) and foraging (Hathaway, 1927; Hellawell, 1971) activities.

The inter-specific difference observed during this experiment is likely due to the contrasted thermal requirements and tolerances of the three species studied. Indeed, the optimum temperature for $S$. cephalus ranges between 12 and $25^{\circ} \mathrm{C}$ (Souchon and Tissot, 2012), the one of $P$. toxostoma between 16 and $25^{\circ} \mathrm{C}$ (Gozlan, 1998), whereas the upper tolerance limit of B. barbatula is colder, around $19^{\circ} \mathrm{C}$ (Elliott et al., 1996). Outside their thermal range, species are under thermal stress that is generally characterized by lethargy at cooler temperatures, and sudden activity sequences and rapid breathing movements at warmer temperatures (Elliott, 1981). The temperatures selected for our experiment made it possible to assess such behavioural changes while keeping temperature within tolerance limits. At $10^{\circ} \mathrm{C}, S$. cephalus and P. toxostoma were indeed under "hypo-thermal" stress: their metabolism was likely slowed down to avoid energy consumption, probably resulting in the observed reduced SSD. Both species of cyprinids were within their optimal thermal range at $20^{\circ} \mathrm{C}$, explaining the increased SSD behaviour. By contrast, $B$. barbatula was within its optimal thermal range at $10^{\circ} \mathrm{C}$, and its proportion of sediment surface disturbed was roughly equivalent to the one of both cyprinid species at $20^{\circ}$ C. B. barbatula was however under "hyper-thermal" stress at $20^{\circ} \mathrm{C}$ resulting in an accelerated metabolism and subsequently an increase in SSD activity.

Differences between species were also found in terms of patterns in the surface disturbed. Overall, the three species disturbed surface sediment particles in a non-random manner with patches of white sand appearing at the surface. However, it seems that B. barbatula tended to dig more patches that were larger on average than the other two species for which the small number and size of patches disturbed were similar. Several activities may generate SSD by fish such as: (i) foraging activity with the ingestion, digestion and excretion of sediment into the water column (Flecker, 1997; Statzner et al., 2003b; Pledger et al., 2014); (ii) displacement of fine particulate matter (Zhang et al., 2004); (iii) burrowing activity (Shirakawa et al., 2013); (iv) nest digging (Moore, 2006); or (v) swimming activity near the substratum (personal observation). In our study, fish observations conducted during the experiments have enabled us to highlight that SSD was mainly due both to foraging and swimming near the sediment surface. Being a benthic fish species, $B$. barbatula was also observed to excavate sand grains to bury and probably to take refuge, resulting in moderate-sized patches of sediment disturbed. By contrast, the two cyprinid species rather tended to produce patches more evenly distributed across the bed. 
Table 1. Summary statistics of the surface sediment disturbance metrics derived from the pictures analysis. Mean and standard deviation across the eight replicates are given.

\begin{tabular}{|c|c|c|c|}
\hline & Barbatula barbatula & Squalius cephalus & Parachondrostoma toxostoma \\
\hline \multicolumn{4}{|c|}{ Surface disturbed $\left(\% . g^{-1}\right)$} \\
\hline $10^{\circ} \mathrm{C}$ & $4.90 \pm 1.56$ & $1.70 \pm 0.79$ & $1.13 \pm 0.66$ \\
\hline $20^{\circ} \mathrm{C}$ & $10.52 \pm 1.74$ & $4.98 \pm 1.30$ & $3.16 \pm 1.41$ \\
\hline \multicolumn{4}{|c|}{ Number of patches after 10 days per gram } \\
\hline $10^{\circ} \mathrm{C}$ & $16.17 \pm 2.16$ & $6.27 \pm 1.85$ & $8.62 \pm 2.09$ \\
\hline $20^{\circ} \mathrm{C}$ & $23.67 \pm 6.20$ & $7.09 \pm 4.22$ & $9.58 \pm 2.15$ \\
\hline \multicolumn{4}{|c|}{ Mean patch area $(\log )$ per gram } \\
\hline $10^{\circ} \mathrm{C}$ & $0.74 \pm 0.15$ & $0.33 \pm 0.06$ & $0.38 \pm 0.09$ \\
\hline $20^{\circ} \mathrm{C}$ & $0.94 \pm 0.13$ & $0.42 \pm 0.10$ & $0.42 \pm 0.10$ \\
\hline
\end{tabular}

The warmer temperature resulted in a larger surface disturbed for all species, but did not result in significantly more and larger patches being disturbed when compared with $10^{\circ} \mathrm{C}$. This counter-intuitive outcome is likely an artefact of the experimental design. Indeed, experimental units are enclosed spaces, where the number and size of patches cannot increase indefinitely. However, to limit this experimental bias, the experiment concluded after 10 days, since it appeared that the proportion of surface disturbed reached a plateau. Conducting a finer analysis of the position and size of appearing white sand patches throughout the 10 days of experiment would likely strengthen our results.

Other technical constraints induced by our experimental design in small-size aquaria hinder to extrapolate these findings to more natural lotic conditions. First, despite the innovative nature of this experiment in microcosms, it is a preliminary approach that deserves to be applied ex situ with more realistic stream flow conditions (e.g., flumes, larger sediment diameters; see such experimental designs in: Statzner et al., 2000; Pledger et al., 2014) or in situ, in both lentic and lotic systems. In streams, water flow can indeed hide the movement of particles due to bioturbation by invertebrates and small fish that have thus limited direct geomorphological implications (Statzner, 2012). Fine sediment displacements by foraging can also be harder due to water-working by the flow that consolidate and structure the bed surface. However, benthic foraging fishes have also been reported to undo the water-worked imbricate structures (Pledger et al., 2014), thereby potentially counteracting the sediment consolidation by flow or other lotic organisms (e.g., plants, aquatic insects; Statzner, 2012). Stream flow might also influence foraging and swimming activities as fish often feed whilst facing upstream into the flow (Pledger et al., 2014), and consequently, the nature of SSD. Accounting for the close tangling between stream flow and SSD by fish activities would likely help better understanding their relative effect in natural systems.

Second, our experimental design limited to the comparison of two contrasted temperatures prevented us to identify potential threshold temperatures above which SSD started to increase or decrease. Such thermal thresholds in sediment reworking have been reported in White et al. (1987) for oligochaetes experiencing cycles of fall and rise temperatures between 4 and $20^{\circ} \mathrm{C}$, and in
Berkenbusch and Rowden (1999) who followed the rate of sediment expulsion by a burrowing shrimp over a 12 -month period. Nevertheless, most other previous studies that have focused on the relationship between temperature and sediment reworking have been limited to two or three temperature treatments (Ouellette et al., 2004; Maire et al., 2007), probably for practical and technical constraints. Further experimental work conducted in a controlled temperature room where a continuous warming would be simulated would make it possible to precisely measure the fine relationship between temperature and SSD and to identify a potential peak activity in fish sediment disturbance activity.

Third, it should be noted that our experiment was limited to three fish species, thus neglecting other fish that are known to be active streambed sediments bioturbators either by feeding or swimming (e.g., the barbel Barbus barbus L.1758: Pledger et al., 2014; the gudgeon Gobio gobio L.1758: Statzner et al., 2003b; Statzner and Sagnes, 2008; larval lamprey: Shirakawa et al., 2013) or nest digging (e.g., salmonids: De Vries, 2012), but also other zoogeomorphic animals such as crayfish (e.g., Statzner et al., 2000) or benthic macro-invertebrates (e.g., De Nadaï-Monoury et al., 2013). Moreover, due to limited space, a single fish was placed into each aquarium preventing all complex biotic interactions known to affect bioturbating activities. In addition, using single fishes has limited our ability to study the joint effects of several bioturbators on physical interactions among sediment surface modifications (Statzner and Sagnes, 2008). All these experimental constraints suggest that a great caution should be exercised if extrapolating these preliminary results to the whole fish communities and more natural conditions.

In the context of the ongoing climate change, our finding that water warming could potentially increase SSD by fish may have important consequences for both physical and geomorphological processes and aquatic ecosystem functioning. This warming, simulated by a temperature of $20^{\circ} \mathrm{C}$, seems realistic in the streams of the Garonne catchment for the end of the 21st century according to the regional climate models (ALADIN climate model; Sevault et al., 2014). Among the potential impacts of an increase in SSD by fish in the future are the increased erodibility of sediment surface and fine particles transport in rivers (Pledger et al., 2014). They could result 
simultaneously in waters with higher suspended solids and fine elements (e.g., organic detrital matter) concentrations, but lower fine sediment volumes (Statzner, 2012) in local places such as deposition areas. Fine sediment removal may subsequently affect negatively biological communities by reducing the establishment and presence of sessile or movement-limited insects (Pringle et al., 1993) and reducing bed biofilms (Statzner et al., 2000) that indirectly affect leaf decomposition processing. In lentic waters, turbidity could be hastened and concentrations in nutrients and organic material higher due to the resuspension of sediments to the water column through bioturbation by fish (e.g., Breukelaar et al., 1994; Matsuzaki et al., 2009), resulting subsequently in phytoplankton blooming and water eutrophication, already enhanced by warming (Jeppesen et al., 2010). Changes in community composition (Matsuzaki et al., 2009) and vertical distribution of benthic fauna (Persson and Svensson, 2006b) due to predation by benthivorous fish may also impact nutrients fluxes as well as the incorporation of organic matter into the benthic food web (Maire et al., 2010), especially at higher temperatures (Zhang et al., 2013).

To conclude, given that benthic foraging is a common feeding behaviour in freshwater environments observed all year round and that it appears a substantial zoogeomorphic mechanism (Pledger et al., 2014), SSD by fish should not be overlooked in future research assessing the potential impacts of climate change on zoogeomorphology. In addition, many cool- and warm-water benthic fish species are forecasted to expand their distribution in the coming decades while some others are expected to contract (Buisson et al., 2008; Lyons et al., 2010). As climate change impacts both habitats and food sources, the distribution of some geomorphologically active animals may change dramatically, affecting subsequently the zoogeomorphic patterns of the influences and intensities of these impacts (Butler, 2012). Hence, these issues should be urgently addressed.

Acknowledgements. We are grateful for the help provided by $\mathrm{S}$. Jean and F. Dauba during the experiment and fish sampling. We thank Météo-France for providing present and future climate data extracted from the ALADIN model. This work has been carried out as a part of "ADAPT'EAU" (ANR-11-CEPL-008), a project supported by the French National Research Agency (ANR) within the framework of "The Global Environmental Changes and Societies (GEC\&S) programme".

\section{References}

Berkenbusch K. and Rowden A.A., 1999. Factors influencing sediment turnover by the burrowing ghost shrimp Callianassa filholi (Decapoda: Thalassinidea). J. Exp. Mar. Biol. Ecol., 238, 283-292.

Biles C.L., Paterson D.M., Ford R.B., Solan M. and Raffaelli D.G., 2002. Bioturbation, ecosystem functioning and community structure. Hydrol. Earth Syst. Sci., 6, 999-1005.
Bouchard P., Chappaz R., Cavalli L. and Brun G., 1998. Influence of environmental variables on the growth of Leuciscus cephalus (Linnaeus 1766), in the River Durance, South-east France. Ann. Limnol. - Int. J. Lim., 34, 193-200.

Brett J.R., 1971. Energetic responses of salmon to temperature. A study of some thermal relations in the physiology and freshwater ecology of sockeye salmon (Oncorhynchus nerka). Am. Zool., 11, 99-113.

Breukelaar A.W., Lammens E.H.R.R., Breteler J.G.P.K. and Tátrai I., 1994. Effects of benthivorous bream (Abramis brama) and carp (Cyprinus carpio) on sediment resuspension and concentrations of nutrients and chlorophyll a. Freshw. Biol., 32, 113-121.

Brown J.H., Gillooly J.F., Allen A.P., Savage V.M. and West G.B., 2004. Toward a metabolic theory of ecology. Ecology, 85, 1771-1789.

Bubnová R., Hello G., Bénard P. and Geleyn J.-F., 1995. Integration of the fully elastic equations cast in the hydrostatic pressure terrain-following coordinate in the framework of the ARPEGE/Aladin NWP system. Mon. Wea. Rev., 123, 515-535.

Buisson L., Thuiller W., Lek S., Lim P. and Grenouillet G., 2008. Climate change hastens the turnover of stream fish assemblages. Glob. Change Biol., 14, 2232-2248.

Butler D.R., 2012. The impact of climate change on patterns of zoogeomorphological influence: examples from the Rocky Mountains of the Western U.S.A. Geomorphology, 157-158, 183-191.

Cadée G.C., 1979. Sediment reworking by the polychaete Heteromastus filiformis on a tidal flat in the Dutch Wadden Sea. Neth. J. Sea Res., 13, 441-456.

Caradec S., Grossi V., Hulth S., Stora G. and Gilbert F., 2004. Macrofaunal reworking activities and hydrocarbon redistribution in an experimental sediment system. J. Sea Res., 52, 199-210.

Chappaz R., Brun G. and Olivari G., 1989. Données nouvelles sur la biologie et l'écologie d'un poisson Cyprinidé peu étudié Chondrostoma toxostoma (Vallot 1936). Comparaison avec Chondrostoma nasus (L., 1766). C.R. Acad. Sci. Paris, 309, 181-186.

Cressie N.A.C., 1993. Statistics for Spatial Data: Revised Edition, Wiley, New York, 928 p.

De Nadaï-Monoury E., Lecerf A., Canal J., Buisson L., Laffaille P. and Gilbert F., 2013. A cost-effective method to quantify biological surface sediment reworking in streams. Hydrobiologia, 713, 115-125.

De Vries P., 2012. Salmonid influence on rivers: a geomorphic fish tail. Geomorphology, 157-158, 66-74.

Elliott J.M., 1981. Some aspects of thermal stress on freshwater teleosts. In: Pickering A.D. (ed.), Stress and Fish, Academic Press, London/New-York, 209-245.

Elliott J.M., Hurley M.A. and Allonby J.D., 1996. A functional model for maximum growth of immature stone loach, Barbatula barbatula, from three populations in north-west England. Freshw. Biol., 36, 547-554.

Flecker A.S., 1996. Ecosystem engineering by a dominant detritivore in a diverse tropical stream. Ecology, 77, 1845-1854.

Flecker A.S., 1997. Habitat modification by tropical fishes: environmental heterogeneity and the variability of interaction strength. J. N. Am. Benthol. Soc., 16, 286-295. 
Flecker A.S. and Taylor B.W., 2004. Tropical fishes as biological bulldozers: density effects on resource heterogeneity and species diversity. Ecology, 85, 2267-2278.

Fry F.E.J., 1947. Effects of the environment on animal activity. University of Toronto Studies Biological Series, No. 55. Publ. Ontario Fisher. Res. Lab., 68, 1-62.

Gilbert F., Hulth S., Grossi V., Poggiale J.-C., Desrosiers G., Rosenberg R., Gerino M., François-Carcaillet F., Michaud E. and Stora G., 2007. Sediment reworking by marine benthic species froom Gullmar Fjord (Western Sweden): importance of faunal biovolume. J. Exp. Mar. Biol. Ecol., 348, 133-144.

Gillooly J.F., Brown J.H., West G.B., Savage V.M. and Charnov E.L., 2001. Effects of size and temperature on metabolic rate. Science, 293, 2248-2251.

Gottesfeld A.S., Hassan M.A., Tunnicliffe J.F. and Poirier R.W., 2004. Sediment dispersion in salmon spawning streams: the influence of floods and salmon redd construction. J. Am. Water Resour. Assoc., 40, 1071-1086.

Gozlan R.E., 1998. Environmental biology and morphodynamics of the sofie Chondrostoma toxostoma (Cyprinidae), with emphasis on early development. PhD Thesis, University of Hertfordshire, UK.

Greig-Smith P., 1952. The use of random and contiguous quadrats in the study of the structure of plant communities. Ann. Bot., 16, 293-316.

Harborne A.R., 2013. The ecology, behaviour, and physiology of fishes on coral reef flats, and the potential impacts of climate change. J. Fish Biol., 83, 417-447.

Hathaway E.S., 1927. The relation of temperature to the quantity of food consumed by fishes. Ecology, 8, 428-434.

Heldman J.E., Gunnarsson J.S., Samuelsson G. and Gilbert F., 2011. Particle reworking and solute transport by the sediment-living polychaetes Marenzelleria neglecta and Hediste diversicolor. J. Exp. Mar. Biol. Ecol., 407, 294-301.

Hellawell J.M., 1971. The autecology of the chub, Squalius cephalus (L.), of the River Lugg and the Afon Llynfi. Freshwater Biol., 1, 369-387.

Hijmans R.J. and van Etten J., 2013. Raster: Geographic data analysis and modeling. R package version 2.1-16.

Hollertz K. and Duchêne J.C., 2001. Burrowing behavior and sediment reworking in the heart urchin Brissopsis lyrifera Forbes (Spatangoida). Mar. Biol., 139, 951-957.

Holtgrieve G.W. and Schindler D.E., 2010. Marine-derived nutrients, bioturbation, and ecosystem metabolism: reconsidering the role of salmon in streams. Ecology, 92, 373-385.

Horoszewicz L., 1973. Lethal and "disturbing" temperatures in some fish species from lakes with normal and artificially elevated temperature. J. Fish Biol., 5, 165-181.

Huet M., 1959. Profiles and biology of western European streams as related to fish management. Trans. Am. Fish. Soc., 88, 155-163.

Ieno E.N., Solan M., Batty P. and Pierce G.J., 2006. How biodiversity affects ecosystem functioning: roles of infaunal species richness, identity and density in the marine benthos. Mar. Ecol. Prog. Ser., 311, 263-271.

Jeppesen E., Meerhoff M., Holmgren K., González-Bergonzoni I., Mello F.T., Declerck S.A.J., Meester L.D., Søndergaard M., Lauridsen T.L., Bjerring R., Conde-Porcuna J.M., Mazzeo N., Iglesias C., Reizenstein M., Malmquist H.J., Liu Z., Balayla D. and Lazzaro X., 2010. Impacts of climate warming on lake fish community structure and potential effects on ecosystem function. Hydrobiologia, 646, 73-90.

Johnson M.F., Rice S.P. and Reid I., 2010. Topographic disturbance of subaqueous gravel substrates by signal crayfish (Pacifastacus leniusculus). Geomorphology, 123, 269-278.

Jones C.G., Lawton J.H. and Shachak M., 1994. Organisms as ecosystem engineers. Oikos, 69, 373-386.

Kassahn K.S., Crozier R.H., Pörtner H.O. and Caley M.J., 2009. Animal performance and stress: responses and tolerance limits at different levels of biological organisation. Biol. Rev., 84, 277-292.

Keith P., Persat H., Feunteun E. and Allardi J., 2011. Les poissons d'eau douce de France, Biotope \& Museum National d'Histoire Naturelle, Paris, 552 p.

Logez M., Bady P. and Pont D., 2012. Modelling the habitat requirement of riverine fish species at the European scale: sensitivity to temperature and precipitation and associated uncertainty. Ecol. Freshw. Fish, 21, 266-282.

López-Olmeda J.F. and Sánchez-Vázquez F.J., 2011. Thermal biology of zebrafish (Danio rerio). J. Therm. Biol., 36, 91-104.

Lyons J., Stewart J.S. and Mitro M., 2010. Predicted effects of climate warming on the distribution of 50 stream fishes in Wisconsin, U.S.A. J. Fish Biol., 77, 1867-1898.

Maire O., Duchêne J.C., Gremare A., Malyuga V.S. and Meysman F.J.R., 2007. A comparison of sediment reworking rates by the surface deposit-feeding bivalve Abra ovata during summertime and wintertime, with a comparison between two models of sediment reworking. J. Exp. Mar. Biol. Ecol., 343, 21-36.

Maire O., Merchant J.N., Bulling M., Teal L.R., Grémare A., Duchêne J.C. and Solan M., 2010. Indirect effects of non-lethal predation on bivalve activity and sediment reworking. J. Exp. Mar. Biol. Ecol., 395, 30-36.

Mann R.H.K., 1976. Observations on the age, growth, reproduction and food of the chub Squalius cephalus (L.) in the River Stour, Dorset. J. Fish Biol., 8, 265-288.

Marmonier P., Archambaud G., Belaidi N., Bougon N., Breil P., Chauvet E., Claret C., Cornut J., Datry T., Dole-Olivier M.J., Dumont B., Flipo N., Foulquier A., Gerino M., Guilpart A., Julien F., Maazouzi C., Martin D., Mermillod-Blondin F., Montuelle B., Namour P., Navel S., Ombredane D., Pelte T., Piscart C., Pusch M., Stroffek S., Robertson A., Sanchez-Perez J.M., Sauvage S., Taleb A., Wantzen M. and Vervier P., 2012. The role of organisms in hyporheic processes: gaps in current knowledge, needs for future research and applications. Ann. Limnol. - Int. J. Lim., 48, 253-266.

Matsuzaki S.-I.S., Usio N., Takamura N. and Washitani I., 2009. Contrasting impacts of invasive engineers on freshwater ecosystems: an experiment and meta-analysis. Oecologia, $158,673-686$.

Montgomery D.R., Buffington J.M., Peterson N.P., Schuett-Hames D. and Quinn T.P., 1996. Stream-bed scour, egg burial depth, and the influence of salmonid spawning on bed surface mobility and embryo survival. Can. J. Fish. Aquat. Sci., 53, 1061-1070.

Montserrat F., Van Colen C., Provoost P., Milla M., Ponti M., Van den Meersche K., Ysebaert T. and Herman P.M.J., 2009. Sediment segregation by biodiffusing bivalves. Estuar. Coast. Shelf S., 83, 379-391. 
Moore J.W., 2006. Animal ecosystem engineers in streams. BioScience, 56, 237-246.

Moore J.W., Schindler D.E., Carter J.L., Fox J.M., Griffiths J. and Holtgrieve G.W., 2007. Biotic control of stream ecosystem fluxes: spawning salmon drive nutrient and matter export. Ecology, 88, 1278-1291.

Orvain F. and Sauriau P.-G., 2002. Environmental and behavioural factors affecting activity in the intertidal gastropod Hydrobia ulvae. J. Exp. Mar. Biol. Ecol., 272, 191-216.

Orvain F., Sauriau P.G., Sygut A., Joassard L. and Le Hir P., 2004. Interacting effects of Hydrobia ulvae bioturbation and microphytobenthos on the erodibility of mudflat sediments. Mar. Ecol. Prog. Ser., 278, 205-223.

Ouellette D., Desrosiers G., Gagne J.P., Gilbert F., Poggiale J.C., Blier P.U. and Stora G., 2004. Effects of temperature on in vitro sediment reworking processes by a gallery biodiffusor, the polychaete Neanthes virens. Mar. Ecol. Prog. Ser., 266, 185-193.

Persson A. and Svensson J.M., 2006a. Effects of benthivorous fish on biogeochemical processes in lake sediments. Freshw. Biol., 51, 1298-1309.

Persson A. and Svensson J.M., 2006b. Vertical distribution of benthic community responses to fish predators, and effects on algae and suspended material. Aquat. Ecol., 40, 85-95.

Peterson D.P. and Foote C.J., 2000. Disturbance of small-stream habitat by spawning sockeye salmon in Alaska. Trans. Am. Fish. Soc., 129, 924-934.

Pledger A.G., Rice S.P. and Millett J., 2014. Reduced bed material stability and increased bedload transport caused by foraging fish: a flume study with juvenile Barbel (Barbus barbus). Earth Surf. Proc. Land., 39, 1500-1513.

Pringle C.M., Blake G.A., Covich A.P., Buzby K.M. and Finley A., 1993. Effects of omnivorous shrimp in a montane tropical stream: sediment removal, disturbance of sessile invertebrates and enhancement of understory algal biomass. Oecologia, 93, 1-11.

R Development Core Team, 2011. R: A Language and Environment for Statistical Computing. R Foundation for Statistical Computing, Vienna, Austria.

Reise K., 2002. Sediment mediated species interactions in coastal waters. J. Sea Res., 48, 127-141.

Roozen F.C.J.M., Lurling M., Vlek H., Kraan E.A.J.V.D.P., Ibelings B.W. and Scheffer M., 2007. Resuspension of algal cells by benthivorous fish boosts phytoplankton biomass and alters community structure in shallow lakes. Freshw. Biol., 52, 977-987.

Scheirer C., Ray W. and Hare N., 1976. Analysis of ranked data derived from completely randomized factorial designs. Biometrics, 32, 429-434.
Sevault F., Somot S., Alias A., Dubois C., Lebeaupin-Brossier C., Nabat P., Adloff F., Deque M. and Decharme B., 2014. A fully coupled Mediterranean regional climate system model: design and evaluation of the ocean component for the 1980-2012 period. Tellus A, 66, 23967.

Shirakawa H., Yanai S. and Goto A., 2013. Lamprey larvae as ecosystem engineers: physical and geochemical impact on the streambed by their burrowing behavior. Hydrobiologia, 701, 313-322.

Souchon Y. and Tissot L., 2012. Synthesis of thermal tolerances of the common freshwater fish species in large Western Europe rivers. Knowl. Manag. Aquat. Ecosyst., 405, 03.

Statzner B., 2012. Geomorphological implications of engineering bed sediments by lotic animals. Geomorphology, 157-158, 49-65.

Statzner B. and Peltret O., 2006. Assessing potential abiotic and biotic complications of crayfish-induced gravel transport in experimental streams. Geomorphology, 74, 245-256.

Statzner B. and Sagnes P., 2008. Crayfish and fish as bioturbators of streambed sediments: assessing joint effects of species with different mechanistic abilities. Geomorphology, 93, 267-287.

Statzner B., Fièvet E., Champagne J.-Y., Morel R. and Herouin E., 2000. Crayfish as geomorphic agents and ecosystem engineers: biological behavior affects sand and gravel erosion in experimental streams. Limnol. Oceanogr., 45, 1030-1040.

Statzner B., Peltret O. and Tomanova S., 2003a. Crayfish as geomorphic agents and ecosystem engineers: effect of a biomass gradient on baseflow and floodinduced transport of gravel and sand in experimental streams. Freshw. Biol., 48, 147-163.

Statzner B., Sagnes P., Champagne J.-Y. and Viboud S., 2003b. Contribution of benthic fish to the patch dynamics of gravel and sand transport in streams. Water Resour. Res., 39, 1-17.

White D.S., Klahr P.C. and Robbins J.A., 1987. Effects of temperature and density on sediment reworking by Stylodrilus heringianus (Oligochaeta: Lumbriculidae). J. Great Lakes Res., 13, 147-156.

Zhang L., Liao Q., He W., Shang J. and Fan C., 2013. The effects of temperature on oxygen uptake and nutrient flux in sediment inhabited by molluscs. J. Limnol., 72, 13-20.

Zhang L., Shang J., He W., You B. and Fan C., 2014. The role of tubificid worms (Limnodrilus hoffmeisteri) in sediment resuspension: a microcosm study. Ann. Limnol. - Int. J. Lim., 50, 253-260.

Zhang Y., Richardson J.S. and Negishi J.N., 2004. Detritus processing, ecosystem engineering and benthic diversity: a test of predator-omnivore interference. J. Anim. Ecol., 73, 756-766. 